\title{
Batik Packaging Design for Creative Industry and Sustainability
}

\author{
Farid Abdullah* \\ Art Education Department \\ Universitas Pendidikan Indonesia \\ Bandung, Indonesia \\ *farid.abdullah@upi.edu
}

\author{
Bambang Tri Wardoyo ${ }^{1,2}$, Aneeza Mohd. Adnan ${ }^{1,2}$ \\ ${ }^{1}$ FSRD \\ ${ }^{1}$ Trisakti University, ${ }^{2}$ Universiti Teknologi MARA \\ ${ }^{1}$ Jakarta, Indonesia, ${ }^{2}$ Shah Alam, Malaysia \\ bambangtriwardoyo@trisakti.ac.id
}

\begin{abstract}
Creative industries were intensified in the Industrial Revolution 4.0 era. The contribution of the creative industries can sustain the economic community. Indonesia has many creative products, one of which is the batik industry. Many Indonesian batik industries are MSME (Micro, Small and Medium Enterprises) which do not yet have adequate packaging, even improvised. Direct packaging also promotes and image of the batik industry. Batik product packaging also has not considered the sustainability of environmentally friendly products. This paper uses a research and development method, in the form of packaging creation for batik packaging for MSME products. Batik product packaging is also demanded to be environmentally responsible. The findings of this paper are: good packaging, environmentally friendly, is a form of responsibility and is able to provide added value to the Indonesian batik industry. The packaging must be well designed, aesthetically, informative, but also sustainable.
\end{abstract}

Keywords-batik, packaging, design, creative industry, sustainable

\section{INTRODUCTION}

The problem of the limitations of the earth in providing natural resources needed for the survival of all creatures on earth then gave birth to the concept of sustainability development which is expected to be applied in every human activity. The concept of sustainability development is to change the way of thinking of many people, including designers, about using limited natural resources responsibly [1]. Within this framework, the design discipline for sustainable design has emerged, in the broadest and most inclusive sense it can be defined as: design, education and research practices that, in one way or another, contribute to responsible sustainable development.

Packaging issues are also related to cultural differences. The awareness of the importance of packaging in each country is different, and this has made the position of Indonesian product packaging still low in competition. There are many considerations behind the existence of a packaging such as size, shape, material, color, text, to the product brand [2]. This difference then also affects the initiative of businesses or MSMEs to design their packaging [3]. Indeed, packaging is an important part because it functions not only as a protection for the product, but also as a promotional medium to attract the next consumer. Through packaging, many consumers decide to purchase a product [4]. The appearance of the packaging of a product has an impact on consumers, because through packaging, the message from the contents of the product in it, either through written information, or the appearance of a packaging that gives an image to consumers [5].

The problem with products produced by Indonesian MSMEs (Micro, Small, and Medium Enterprises) is competition with foreign products such as China, Singapore, Thailand, Japan and Malaysia which have more attractive packaging. Currently in Indonesia there are approximately 59.2 million MSMEs, with quality products that are competitive, but less able to attract consumers to buy because they are poorly packaged [6]. The results of the study on the marketing of SME products show that there are still many Indonesian MSME players who have not met product quality and packaging standards. This condition makes the competitiveness of local products very low when compared to foreign products.

Since the 90's, public attention has shifted partly to the product level, namely to product design that has a low environmental impact. This attention was initially focused on redesigning the individual qualities of individual products (eg reducing the amount of materials used in a product, facilitating disassembly, etc.). there are early efforts to integrate environmental sustainability in product design into green design labels. It was only then, particularly in the second half of the 90s, that this design approach was expanded to systematically address the entire product life cycle, from resource extraction to the end of the product. This is commonly referred to as product life cycle design, Eco Design or environmental sustainability product design. In those years, the environmental impacts caused by the production, use and disposal of products and how to assess them became clearer. New methods for assessing the environmental impact of products (inputs and outputs between technosphere, geosphere and biosphere). 


\section{METHODS}

This research is the creation of packaging using research and development methods. This research approach is descriptive qualitative. The descriptive approach aims to describe the existing conditions and then describe them. The descriptive concept can be applied in research on visual language, art, and design on the condition that the research topic involves observation of the object under study [7], while the qualitative approach is flexible and flexible based on field conditions, with data collection in the form of interviews and documentation in the field [8].

In the research and development method, validation and triangulation aspects are very important. Validity is the degree of consistency between the data obtained on the research object and the data used by the researcher. Valid data are data that are not different and reported by researchers [9]. The data collection process needs to be tested for validity through data triangulation. The definition of data triangulation is checking data with different sources and times. This triangulation technique is carried out by connecting some information and documentation [10] related to the development of sustainable packaging.

\section{RESULTS}

Some researchers have adopted a more stringent definition of sustainability design. Sustainable design is needed to produce solutions that are mutually beneficial to the communities around us (especially unreached people and disadvantaged groups of people), including for the natural environment and economic systems (globally but especially locally).

In the late 90's design researchers also began to see nature as a source of inspiration to tackle sustainability. One of these approaches is known as the Cradle to Cradle (C2C) design, whose main principle 'waste equals food' focuses on creating an open cycle for 'biological nutrients' (i.e. organic matter) and a closed cycle for 'technical nutrients' (i.e. inorganic). or synthetic materials). Different from product Lifecycle Design, $\mathrm{C} 2 \mathrm{C}$ focuses primarily on the flow of product from material resources, and this may result in neglecting some other environmental (and potentially more important) aspects (eg. energy consumption in the usage phase).

See the flow diagram for the creation of a sustainable packaging design and become part of the creative economy below (Figure 1).

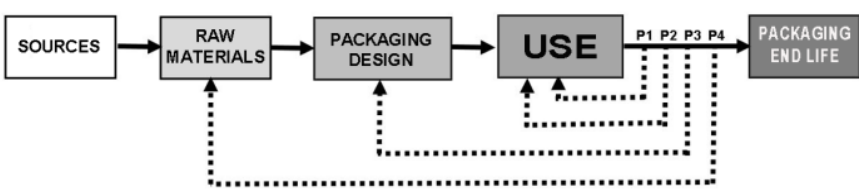

Fig. 1. Creation of sustainable design (source: Jayakrisna).
In the early stages, the activities of creating sustainable packaging and part of the creative economy were sources. The concept of resources has been applied in various fields of science. The concept of resources deals with geography, economics, biology and ecology, computer science, management, and human resources, including design. Resources are closely related to the concepts of availability, sustainability, conservation and management. Its application in human life, there are commercial or non-commercial factors that require resource management [11]. A resource is any material that occurs naturally and can be exploited which according to society is beneficial for its economic and material welfare [12]. People who have geographic information must understand that "resources" are a cultural concept. Resources are any physical material that is part of the earth that humans need and value. Natural materials become resources when humans value them.

The second stage is related to raw materials. When these basic materials have been obtained, the next step is processing them into raw materials. The definition of raw materials is commodities and sold in factor markets, raw materials are the basic materials from which products are manufactured or made [13]. Included in the raw materials are paper, cardboard, duplex, etc.

The third stage is the process of making packaging design. At this stage, the role of the designer is very important. The role of the designer is to design, define concepts, source ideas, make designs, create alternatives, and make final decisions.

The fourth stage is the packaging used by end-user consumers. When the packaging has been produced, then marketed, both by retail stores, the next stage is consumer use. At this stage the packaging is fully used. Some consumers are wise, sometimes reuse packaging that has been used. Most of the other consumers actually use packaging as a collection.

In this fourth stage, it consists of $4 \mathrm{P}$ cycles, namely P1, P2, $\mathbf{P 3}$, and P4. In the P1 phase or the first process, the packaging after it is in the hands of the user, can be used for shopping use. This P1 stage requires understanding and consumer wisdom of sustainable packaging practices. For this reason, information on packaging, that packaging can be reused is very important.

Phase $\mathbf{P 1}$ is the process of using the first continuous stage, where the user uses it for the second time after getting packaging from a retail store. In this first stage, the user shows the responsibility of using the packaging by carrying the packaging for shopping. The role of the design designer in packaging provides information on the second very important use. Information for example: "Help the earth by using this packaging to shop again"

Phase $\mathbf{P 2}$ is the stage when the packaging is reused by the user. In some packaging, reuse by users is often found in paper or duplex packaging. Both of these materials are relatively easy to reuse by users, both for shopping outside the room and for domestic use at home. The important role of parents in giving 
examples to children in reusing packaging is very important in this $\mathrm{P} 2$ phase.

The $\mathbf{P 3}$ phase is carried out when the packaging is melted down, reformed into new packaging. Certain materials such as plastic, styrofoam, or acrylic are very easy to process, melt back into new packaging. Some of the chemical-based packaging, as written above, is very easy to use in everyday packaging. Plastic materials can be melted into a new form of packaging and are different from the original material.

The last stage or $\mathbf{P 4}$ is processing packaging into raw materials. At this stage, it can actually be called the end of life packaging. The shelf life of packaging also needs to be considered, whether it can be used only once, twice or repeatedly because of its excellent strength. At this stage some materials such as acrylic can be melted back and formed into acrylic granules.

Below this a packaging design with the Mega Mendung batik pattern that is environmentally friendly, recyclable and sustainable.

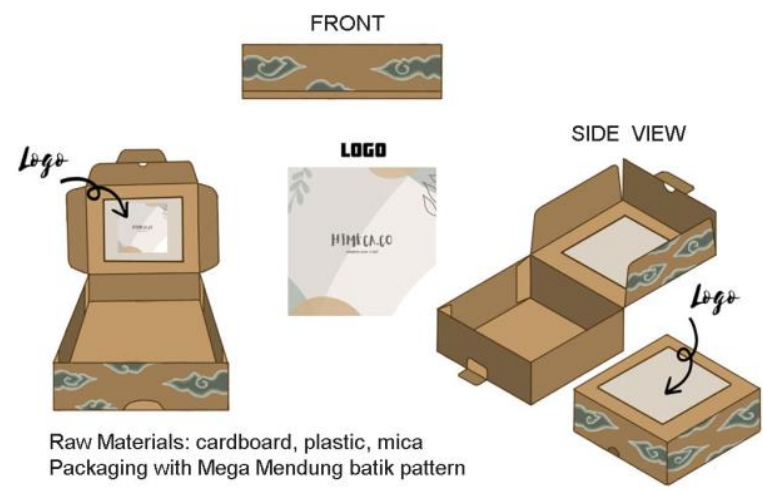

Fig. 2. Batik packaging design for creative industry (Design by: Faiza Roikhatuzahra)

The packaging above (figure 2) shows the front view, side view, the folds and the placement of the logo on the packaging. This packaging design can be used as part of the creative and sustainability industry. The Mega Mendung batik pattern is a characteristic icon representing the Indonesian batik pattern and has been widely recognized by Indonesians.

Sustainability design has broadened its scope and areas of action over time, as various authors such as Vezzoli and Manzini have observed. The focus has evolved from the selection of low environmental impact resources to Life cycle design or Eco product design, to designing environmentally efficient product service systems and to designing social equality and cohesion.
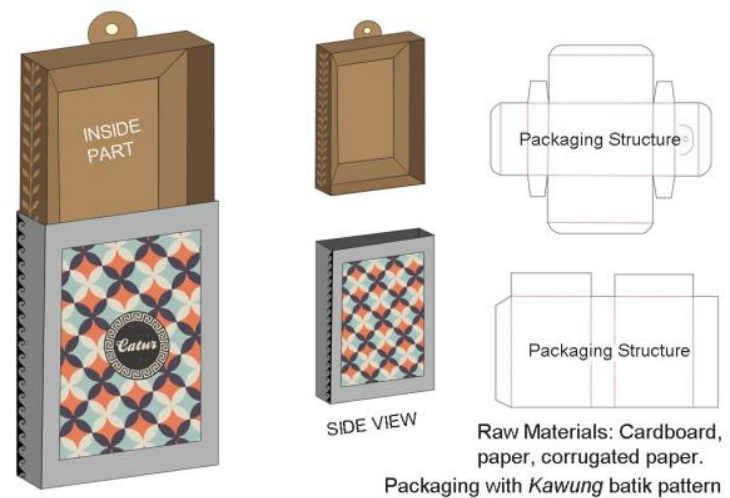

Fig. 3. Batik packaging design for creative industry (Design by: Yuni Catur Wulandari).

The concept of a life cycle approach - from designing the product to designing the stages of the product life cycle, i.e. all the activities required to produce a material and then a product, to distribute it, use it, and ultimately dispose of it - is highly considered in a holistic approach.

Second, the functional approach is conceptualized from an environmental point of view. From an environmental perspective, namely to design and evaluate the environmental sustainability of a product, starting from its function rather than from the physical manifestation of the product itself, it is understood that environmental assessment, and therefore design, must have a reference to the function provided by a given product. Then the design must consider the less than the product service / results obtained by the product.

\section{CONCLUSION}

Sustainability is the responsibility of all parties, including batik MSMEs. Design activities must consider sustainability from the start, starting from concepts, ideas, to consumers. Sustainability, starting from basic materials, processed materials to usage, must be reusable. This form of responsibility at a macro level is the responsibility of protecting the earth, but on a micro level it is also a form of concern for MSMEs and can raise a positive image of the batik business itself.

Apart from being part of the creative industry, MSME batik packaging is also required to be responsible to society. The use of recycled, environmentally friendly, non-disposable materials is a designer's responsibility. Packaging is also important to be creative, aesthetic, informative, but also has the added value of being sustainable. The use of environmentally friendly materials, recycled paper, plastics must be the basic components of sustainable packaging.

\section{REFERENCES}

[1] B. Talarosha, Sustainable Design, Sebuah Pendekatan dalam Perancangan Arsitektur. Medan: Universitas Sumatera Utara, 2013 
[2] B. Rundh, "Linking packaging to marketing: how packaging is influencing the marketing strategy," Br. Food J., vol. 115, no. 11, pp. 1547-15632013.

[3] N. Ahmad, M. Billoo, and A. A. Lakhan, "Effect of product packaging in consumer buying decision," J. Bus. Strateg., vol. 6, no. 2, pp. 1-10, 2012 .

[4] T. Susetyarsi, "Kemasan produk ditinjau dari bahan kemasan, bentuk kemasan dan pelabelan pada kemasan pengaruhnya terhadap keputusan pembelian pada produk minuman mizone di kota semarang," J. STIE SEMARANG (EDISI Elektron), vol. 4, no. 3, pp. 1-28, 2012.

[5] M. E. Apriyanti, "Pentingnya Kemasan terhadap Penjualan Produk Perusahaan," Sosio e-Kons, vol. 10, no. 1, pp. 20-27, 2018.

[6] S. Syamsudin, F. Wajdi, and A. N. Praswati, "Desain kemasan makanan KUB Sukarasa di Desa wisata organik Sukorejo Sragen," Benefit J. Manaj. Dan Bisnis, vol. 19, no. 2, pp. 181-188, 2016.
[7] Sumartono, Metodologi Penelitian Kualitatif Seni Rupa dan Desain Jakarta: Pusat Studi Reka Rancang Visual dan Lingkungan, Fakultas Seni Rupa dan Desain, Universitas Trisakti, 2017.

[8] J. Sarwono and H. Lubis, Metode riset untuk desain komunikasi visual. Yogyakarta: Andi, 2007.

[9] Sugiyono, Memahami penelitian kualitatif. Bandung: Alfabeta, 2005.

[10] K. Rahman, "Pengembangan desain kerajinan anyam bambu Desa Kalinganyar Pulau Kangean,” J. Seni Rupa, vol. 3, no. 03, 2015.

[11] G. T. Miller and S. Spoolman, Living in the environment: principles, connections, and solutions. California: Brook-Cole, 2011.

[12] A. Getis, M. Bjelland, and V. Getis, Introduction to geography. New York: McGraw-Hill Education, 2014.

[13] H. Florén, J. Frishammar, C. Lee, M. Ericsson, and S. Gustafsson, "A framework for raw materials management in process industries," in R\&D Management Conference, Manchester, UK, June, 2013, pp. 26-28. 